Jerzy Oniszczuk

\title{
KILKA UWAG O WARUNKACH POKOJU. MYŚL O CZŁOWIECZEŃSTWIE
}

\section{Wprowadzenie. Konieczność zrozumienia}

Refleksja nad pokojem zwykle zwraca uwagę na wartość pokoju, ale też na sprawę wojny sprawiedliwej jako narzędzia pokoju, na konieczność głoszenia pokoju, kształtowanie propokojowej świadomości ludzi, na alternatywę pokój - zagłada itd. ${ }^{1}$ Mówienie o pokoju to zwłaszcza (czy między innymi) pytania o jego warunki. Po I wojnie światowej, a przed II w 1932 r. Albert Einstein zwrócił się do Zygmunta Freuda z kwestią „Niech mi Pan powie, co popycha człowieka do wojny?”. I dalej próbował dociekać możliwości pokierowania ewolucją psychiki człowieka, aby ten „stał się bardziej odporny na psychozę nienawiści i zniszczenia”. W odpowiedzi Freud zwrócił uwagę na dwa czynniki, które jego zdaniem w najbliższej przyszłości miałyby oddziaływać na zakończenie wojen, a mianowicie „cywilizowana postawa i uzasadniona obawa przed skutkami przyszłej wojny”. Freud nie dożył II wojny światowej, ale jej zbrodnie sprawiły, że Einstein uznał sens nawoływania do pacyfizmu. W 1955 r. w jego ostatnim apelu do ludzi o przetrwanie prosił: „Ponad wszystko pamiętajcie o swoim człowieczeństwie, zapomnijcie o wszystkim innym”2. Uczony próbował sięgnąć do istoty, tj. do konieczności postawienia na świadomość człowieczeństwa każdego, jako szczególnej wartości przetrwania ludzkości. W tym można znaleźć nakaz stałej myśli o człowieczeństwie jako kryterium oceny działań ludzi i ich organizacji. Z poglądem tym koresponduje praktycznie traktowana zasada pomocy bliźniemu. Wspomniana odpowiedź Freuda proponowała optymistyczną myśl, że człowiek rozwinięty kulturowo, rozumniejszy i świadomy niebezpieczeństw postawi tamę wojnie. II wojna

\footnotetext{
1 Zob. w sprawie pacyfizmu: M. Szyszkowska, Etyka, Kresowa Agencja Wydawnicza, Białystok 2010, s. 137-144. O wojnie sprawiedliwej zob. K. Kuźmicz, Pokój z punktu widzenia filozoficznoprawnego, w: Pokój i demokracja, red. M. Szyszkowska, TCHU Dom Wydawniczy, Warszawa 2009, s. 372; J. Oniszczuk, Filozofia i teoria prawa, wyd. 2, C.H. Beck, Warszawa 2012, np. s. 135-137, 165.

2 T. Terzani, Listy przeciwko wojnie, przeł. J. Wachowiak-Finlaison, Wydawnictwo WAB, Warszawa 2012, s. $47-48$.
} 
światowa i to, co po niej nastąpiło, powoduje zdystansowanie wobec prostych, jakoś tam logicznie i humanistycznie przekonywających odpowiedzi liczących na rozwój cywilizacji i zapewnienie przez nią pokoju.

Rzeczywistość pełna konfliktów na świecie ciągle negatywnie weryfikuje diagnozę Freuda i apel Einsteina. Pojawił się nawet problem przetrwania ludzkości ${ }^{3}$.

Po wydarzeniach 11 września 2001 r. pisarz Tiziano Terzani zastanawiał się nad tym, co sprawia, że ludzie wysadzają się w powietrze, popełniają samobójstwa, „płoną w ogniu nowej, rozlewającej się przemocy, wobec której hekatomba Bliźniaczych Wież może się okazać zaledwie epizodem”. Pisarz przekonywał, że nie o usprawiedliwienie i wybaczenie mu chodzi, ale o zrozumienie terroryzmu. Co do źródła tego dążenia do zrozumienia, to odnajdywał je w swoim przekonaniu, że problem terroryzmu nie da się rozwiązać drogą usunięcia terrorystów, ale przyczyn, które ich wykształcają. Następstwo 11 września w postaci interwencji amerykańskiej w Afganistanie sprawiało, że pisarz tym bardziej chciał uzyskać wspomniane rozumienie z własnego oglądu następstw wojny w Afganistanie, którą wówczas w okresie 2001-2002 Amerykanie nazywali „tylko pierwszą fazą”. W tej sytuacji, na podstawie swoistej analogii pisarz mówil, że chce „zrozumieć, co się stanie z resztą świata - naszego świata, świata wszystkich - kiedy ta wojna przeniesie się stąd prawdopodobnie do Iraku, Somalii, Sudanu, może Syrii, Libanu i kto wie dokąd jeszcze". Pisarz przy tym odnotował, że Waszyngton szacował miejsce ukrycia terrorystów w około 60 państwach i uważał, że te, które nie będą współdziałały z USA, będą uznane za wroga. Na tle tych ustaleń myśliciel dziwił się temu, że Europa bardzo słabo zareagowała „przeciwko tej niemal samobójczej nieugiętości Ameryki” i dalej zapytywał „Czy to jest możliwe, że Europa została kolejną wielką ofiarą tej wojny?"4.

W tych warunkach dzień 10 września Terzani pojął jako wyjątkowy punkt odniesienia pod adresem terroryzmu, a jego szczególność polegała na tym, że był to dzień „przed nowym barbarzyństwem, przed ograniczeniem naszej wolności, przed nietolerancją, wojną technologiczną, masakrami więźniów i niewinnych cywilów, przed wielką hipokryzją, konformizmem, obojętnością albo, co gorsza, przed małostkową złością i źle rozumianą dumą. Dzień, po którym nasze marzenia o rosnącej wzajemnej miłości, braterstwie, większym uduchowieniu i większej radości zmieniły się w więcej nienawiści, dyskryminacji, materializmu, więcej bólu”. Po 11 września pisarz nie zauważył, aby ówczesna Ameryka ocknęła się, aby „wszystko przemyśleć: relacje między krajami, między religiami, z naturą, między człowiekiem a człowiekiem”, nie

3 M. Szyszkowska, Odcienie codzienności, Kresowa Agencja Wydawnicza, Białystok 2009, s. 181.

4 T. Terzani, op.cit., s. 40, 78. 
zrobiła rachunku sumienia ${ }^{5}$. Ona poszła drogą banalną i bez namysłu. Terzani opisał ją jako „arogancką, tępą, skoncentrowaną wyłącznie na sobie, tryumfującą w swojej potędze, w swoim bogactwie, bez jakiegokolwiek zrozumienia czy ciekawości w stosunku do reszty świata". O swoich wrażeniach z podróży po Ameryce napisał, że uderzyło go „wszechobecne poczucie wyższości, przekonanie o własnej wyjątkowości i sile, o byciu cywilizacją idealną. Wszystko bez żadnej autoironii”. Kolejną zaś z tego wypływającą refleksją było spojrzenie na „Amerykanów jak na ofiary jakiegoś prania mózgu: wszyscy mówią to samo, myślą tak samo". Zestawiając ich z Koreańczykami, odnajdował różnicę tylko w tym, że Amerykanie uważali, iż „robią to z własnej woli i nie zdają sobie sprawy z tego, że ich konformizm jest owocem wszystkiego, co widzą, piją, słyszą i jedzą". Ale pisarz dostrzegł też, że sprawcom 11 września jako wrogowi niektórzy odmówili „człowieczeństwa” (np. Oriana Fallaci). W ogóle zaś w odmowie człowieczeństwa pisarz odnajdował źródło „bestialstwa wszystkich wojen”. Mówiąc o problemie terroryzmu, pisarz nie tyle zajął się sensem wojny z terrorystami, ale uznawał jako mądrzejsze podjęcie sprawy przyczyn popychających ludzi ku dżihadowi i sprzyjających poglądowi, że zabijanie innych i samobójstwo stanowi ich misję życiową. Zatem, jak twierdził, prawdziwa wiara w nienaruszalność życia oznacza konieczność akceptacji nienaruszalności życia wszystkich ludzi. W innym przypadku pojawia się sprawa dopuszczenia do „setek, tysięcy zabitych - także cywili i nieuzbrojonych - którzy będą ofiarami naszego odwetu"6.

W kontekście znaczenia 11 września i późniejszego zachowania amerykańskiej opinii oraz przebiegu działań wojennych w Afganistanie pisarz znalazł uzasadnienie do przedstawienia tej wojny jako pewnego symbolu, swoistego papierka lakmusowego amerykańskiego „pędu cywilizacyjnego, braku moralności, zdolności zrozumienia, że przemoc rodzi tylko przemoc i że jedynie siłą pokoju, a nie siłą broni możemy rozwiązać problemy, które przed nami stoją"7.

Doświadczenia terrorystyczno-wojenne od 2001 r. do paryskich wydarzeń z listopada 2015 r. sprzyjają ocenie, że był to czas, o którym bardzo trudno powiedzieć, że był to dobry okres pokoju w ujęciu światowym. Natomiast od momentu zamachów paryskich można powiedzieć, że pokój przybrał wyraźniej postać złego pokoju. W każdym razie po 11 września myśleniu o pokoju, jako przesłance globalizacji ${ }^{8}$, towarzyszy myśl, że globalizacja jest związana nie tylko z dobrymi, ale i ze złymi rzeczami. A globalny terroryzm wyraża pewien obszar zła, chociaż go nie wyjaśnia. W czasie terroru zaś, na podobieństwo czasu wojny, pierwsza umiera prawda. Pełnię władzy

Ibidem, s. 8, 9 .

Ibidem, s. 14-16, 28-29.

Ibidem, s. 70.

8 K. Kuźmicz, op.cit., s. 373. 
przejmuje kłamstwo, które usprawiedliwia wszelkie okrucieństwa i niegodziwości wojny. Kształtuje też ono absurd w postaci „wstydu potępienia” wojny jako takiej, ale też umożliwia występek demokracji w postaci unikania zastanowienia się nad wojną. W takiej sytuacji pojawia się pytanie o rolę ludzi próbujących z refleksją podchodzić do świata przemocy. Kwestią jest, czy rzeczywiście wojna może zawieszać sens kultury? W próbie odpowiedzi na to pytanie Palestyńczyk, profesor Edward Said zwraca uwagę na odpowiedzialność intelektualistów, a mianowicie, że ich odpowiedzią na kłamstwa wojny jest poszukiwanie prawdy i „tworzenie pól zrozumienia, a nie pól bitwy". Zatem to od świata intelektualistów oczekuje się rozważań i pytań. I to np. nawet w sytuacji, gdy tzw. najszersza opinia publiczna uznawała oczywistość i konieczność wojny afgańskiej jako słusznej walki świata demokratycznego z terroryzmem. Terzani przypomina, że w „czasach wojny mówienie o pokoju nie może być przestępstwem”, gdyż podnoszenie kwestii jest zasadniczą funkcją myślenia, zaś wątpliwość stanowi podstawę kultury europejskiej. Dlatego próbę usunięcia „wątpliwości z naszych umysłów” pisarz porównał do "chęci pozbawienia naszych płuc tlenu”.

Wśród tych kwestii ważnych do rozważań nad sprawami pokoju są warunki, które mu służą, ale też te, które go niszczą, którym najlepiej jest zapobiegać, albo szukać sposobu rozwiązania. To zaś wymaga stałej wolności myślenia.

\section{Nawiązania filozoficzne do pokoju}

Refleksja dotycząca pokoju ma korzenie przedfilozoficzne. Wzmianki na jej temat pojawiły się w dziełach Homera, a zwłaszcza w poezji Hezjoda, który w Teogonii napisał, że Zeus pojął „kwitnącą Ejrene” (Pokój). Można dodać, że jedna z komedii Arystofanesa nosi tytuł Eirene. W interpretacji Hezjoda odnaleziono uznanie powiązania ładu boskiego z porządkiem ludzkim za pomocą norm wprowadzających „dobry porządek społeczny, sprawiedliwość i pokój” ${ }^{10}$. Zastanawiając się nad porządkiem społecznym, Hezjod przedstawia też obraz miasta sprawiedliwego i miasta pełnego pychy. Fundament ładu ludzkiego postrzega w sprawiedliwości społecznej, zaś gwarantem tego porządku mają być bogowie ${ }^{11}$. Znaczenie dla pokoju starożytni znajdują też w mądrości, która w rozumieniu Ksenofanesa m.in. służy praworządności polis i szczęściu ludzi. Rozwijający tę myśl Eurypides dowodził, że polis potrzebuje

9 T. Terzani, op.cit., s. 76-77, 44-45.

10 O. Murray, Narodziny Grecji, Prószyński i S-ka, Warszawa 2004, s. 87.

11 Ibidem, s. 248-249. 
obywateli mądrych, dobrych, roztropnych i sprawiedliwych, nie zaś takich, „którzy wychowani na mitach, ulegając ich zgubnym wpływom, wzniecają wojny domowe"12.

Zatem to zwłaszcza w mądrości odnajdowano uwarunkowania dobrej polis i prawidłowego postępowania człowieka. Ale fundamentalną kwestią jest, jak sprawić, aby obywatel był mądry, nie mówiąc już o byciu dobrym, roztropnym czy sprawiedliwym. Współcześnie odpowiedź na to pytanie brzmi: jak rozwiązać nierozwiązywalne, jak wydostać się z labiryntu, z którego wyjście nie zostało założone. A taka horrendalna sytuacja zdaje się mieć miejsce współcześnie, w epoce realizacji globalnego scenariusza neoliberalnego, w warunkach rządów jakiejś duszy neohobbesowskiej, kierującej się zasadą powszechnej nieufności i konkurencji, w warunkach niebywałych nierównowag gospodarczych, finansowych, społecznych i nierówności między ludźmi. Myślenie mądrościowo-pokojowe nie wychodzi od jakiegoś radykalnego projektu zniszczenia centrum „zasilania” rządzących ideologii, ale przecież myślenie mądrościowe nie jest pozbawione wiedzy o prawie (swobodzie) człowieka do adekwatnych do opresji form oporu.

Problem konfliktu w takiej czy innej społeczności, w poszczególnych państwach może nie byłby aż tak trudny jak ten, który uwzględnia wojnę między społeczeństwami i państwami. Wojna od czasów starożytnych bardzo często była kwestionowana zarówno z jednostkowego, społecznego, jak i międzypaństwowego punktu widzenia. Już starożytność odkryła, że pokój jest np. warunkiem rozwoju. Uznanie prorozwojowego i humanistycznego znaczenia pokoju ma mocne uzasadnienie. Ale można tu też dodać, że np. średniowieczne poglądy dopuszczały wojnę służącą restytucji pokoju. Jednak nawet takie uzasadnienia nie unieważniają starożytnych spostrzeżeń, że żadna $\mathrm{z}$ wojen nie skończyła łańcucha koszmaru wojen. W przypadku wojen nie działa bowiem np. zasada, że wydarzenie, które najpierw jest tragedią, w formie powtórzenia przyjmuje postać groteski i schodzi z porządku dziejów. Ta zasada nie obowiązuje w stosunku do wojny: każda jest bowiem tragedią, kwestią jest tylko skala tragedii. Do tysięcy opisów wojen i stąd uzasadnień pokoju od czasów najstarszych swój ogromny dopisek wniósł dramat I i II wojny światowej. Opierały się one o gigantyczne liczby osób, które zginęły $(60 \mathrm{mln})$ i niewyobrażalne zniszczenia gospodarek, substancji materialnej oraz kulturalnej, zwłaszcza w Europie. W każdym razie, i zapewne dla tzw. zwykłego człowieka, każdy pokój jest lepszy od najsłuszniejszej wojny. Pokój jest niewyobrażalnym dobrem. Ale co to znaczy każdy pokój, tj. czy ten każdy pokój nie ma swojej jakości i czy ten jakikolwiek pokój ostatecznie wystarczy dla zdrowia człowieka, jeżeli jego perspektywą jest beznadziejność,

12 J. Gajda, Prawo natury i umowa społeczna w filozofii przedsokratejskiej, Wydawnictwo Uniwersytetu Wrocławskiego, Wrocław 1986, s. 108-109. 
a nawet opresja wobec niego? Czy umożliwi globalizację i zdrowie człowieka jego zgoda na taki opresyjny pokój, który nie tyle nie uwzględnia jego dobrego zdrowia czy nawet jakiegoś minimum dla znośnego życia, ale który jest pełen zagrożeń dla ludzi? Nadużywanie pokoju nie jest traktowane jako poprawne korzystanie ze swojego władztwa przez rządzących, stąd też dawno temu pojawiła się kwestia wyzwolenia człowieka od opresyjnego pokoju i jego swobody oporu. Nie rozwijając wątku, można powiedzieć, że pokój zasadniczo kojarzy się z czymś ogromnie wartościowym. Ale też nie jest wykluczone przypuszczenie, że nie każdy pokój stwarza warunki do globalizacji i zdrowia człowieka. Zwłaszcza chodzi tu o „pokój” pełen przemocy i dyskryminacji wobec ludzi.

Niezmiernie wiele zebrano złych doświadczeń płynących z globalnych rządów ideologii neoliberalnej dla człowieka. To jej przepisuje się wygenerowanie niewyobrażalnych różnic dochodowych i wszelkich nierówności, wykluczenia, dyskryminacji oraz powszechności konfliktowego myślenia poprzez wdrożenie wychowania dla konkurencji oraz podążającej za tym praktyki ludzi, społeczeństw i państw. Globalna skala opresyjności neoliberalizmu sprawia, że coraz mniej myślących ludzi uznaje możliwość pozytywnej, organizatorskiej roli neoliberalizmu na świecie. W tej sytuacji wielką, fundamentalną kwestią jest wedle jakiej wizji filozoficznej, w myśl jakiej koncepcji człowieka ma się odbywać dalsza globalizacja. Jak ma wyglądać pokój, który umożliwi dobrą globalizację i pewien dobrostan człowieka. Jaka myśl może podpowiadać warunki, z których spełnieniem negatywną globalizację wyprze globalizacja pozytywna, propokojowa, służąca zdrowiu człowieka. Odpowiedź mądrościowa w podniesionej kwestii i przy tym taka, którą cechuje realność, wydaje się nieomal niewyobrażalna, ot chociażby dlatego, że podejmowane od starożytności próby rozwiązania problemów ludzkich za pomocą konfliktów wojennych zawsze miały u podstaw wielkie pozytywne hasła obrony albo walki o sprawiedliwość, wolność, wyzwolenie czy demokrację itd. Liczne wojny odwoływały się do religii, wplątywały w nie imiona bogów i prowadzone były w imieniu sprawiedliwości czy jedynej prawdziwej, powszechnie rządzącej idei. W każdym razie obecnie niejednokrotnie podkreśla się brak takiej powszechnej idei organizującej ludzi np. do życia w egalitarnym społeczeństwie (np. pisarz O. Pamuk). Kwestią jest tylko, czy na tle doświadczeń z różnymi „ambitnymi” ideologiami taka tradycyjnie pojmowana ogólna organizująca idea jest rzeczywiście niezbędna.

Można przypomnieć, że w stosunku do jakiejś hobbesowskiej wizji świata próbował przedstawić oświeceniowe wyjście już Kant. Ostrzegał przed wojną i proponował pokojowe wyjście ze złej ścieżki. W założeniu jego projektu o sensie wiecznego pokoju pojawiła się myśl, że jest to konieczne zadanie rozumu. Podejście to kontynuuje wspomniane antyczne podejście do pokoju związanego z mądrością ludzką. 
I co więcej, podążając tą droga za pomocą myślenia a contrario, można powiedzieć, że myślenie niepokojowe cechuje niemądrościowe podejścia czy postawy ludzkie. Te podejścia nie liczą się z prawdą, która na wojnie pierwsza umiera. Na przykładzie wojny w Afganistanie pisarz dowodził, że wojna jest wielkim kłamstwem, zaś „Ci, którzy naprawdę się liczą w tej wojnie kłamstw, to spin doktorzy, eksperci od komunikacji, pracownicy public relations. To oni zaciągają zasłonę dymną na bezsens tej wojny i nie dopuszczają, żeby światowa opinia publiczna [...] przyjęła odmienną, moralną perspektywę tych wydarzeń". Co do prawdy o tej wojnie, to w 2002 r. napisał, że „wydaje się tak niewyraźna, że musi być bez przerwy opakowywana, «zarządzana», musi być obiektem sprytnej kampanii reklamowej. Ale taki właśnie stał się nasz świat: reklama zajęła miejsce literatury, slogany poruszają nas bardziej niż wersy poezji. Jedynym sposobem, żeby się temu nie dać, jest obstawanie przy samodzielnym myśleniu i, przede wszystkim, własnym sumieniu”. Wielką rolę w tej wojnie kłamstw odgrywa oddziaływanie na emocje, gdyż te wywoływane przez nieprawdziwe informacje miały sprzyjać usprawiedliwianiu okrucieństw wojny i też „sprawić, że ofiary staną się częścią «nieuniknionej ceny», jaką trzeba zapłacić za uwolnienie świata od niebezpieczeństwa terroryzmu”. Tak zorientowaną amerykańską politykę informacyjną i dezinformacyjną pisarz ocenił jako podsycającą „gniew opinii publicznej w zachodnim świecie” ${ }^{13}$ i sprzyjającą poddawaniu przeciwników wojny „wyrokom sądowym" oraz poddawaniu ich pism cenzurze ${ }^{14}$.

Wspomniana mądrościowa (rozumowa) kwalifikacja propokojowych refleksji Kanta ma u podstaw zasadę człowieczeństwa, która pojawiła się u Einsteina. Kantowska zasada uznaje człowieczeństwo za cel sam w sobie i wskazuje, że tylko w warunkach pokoju możliwa jest jej realizacja. Ze względu na powszechną konieczność tej zasady pojawia się sprawa jej wypełniania w stosunkach wewnątrzpaństwowych i międzynarodowych. Powinnością ludzi i państw jest dążenie do celu, jakim jest wieczny pokój. Nie do przyjęcia są wojny, nawet tzw. sprawiedliwe, gdyż wówczas człowiek traktowany jest w sposób niemoralny, tj. pojawia się jego instrumentalne traktowanie jako środka do celu. Na początku rozdziału drugiego pracy Do wiecznego pokoju znajduje się myśl, że stan pokoju między ludźmi nie jest stanem naturalnym, gdyż jest nim raczej stan wojny ${ }^{15}$. Dostrzegając złe skłonności ludzi, które eksponują się zwłaszcza między narodami, i konfliktowy sposób dochodzenia swych praw, którego wynikiem może być zwycięstwo, filozof uznaje, że pojawiający się wówczas traktat pokojowy zakończy daną wojnę, ale nie położy kresu stanowi wojennemu. Wobec

13 T. Terzani, op.cit., s. 76-77, 111.

14 E. Zarzycka-Bérard, J.-Y. Potel, Maspero, przyjaciel wolności, „Gazeta Wyborcza”, 14-15.11.2015, s. 33-34.

15 „Tj. jeśli nie stan ciągłej erupcji działań nieprzyjacielskich, to jednak ustawicznego nimi zagrożenia”. 
tego jednak, że „rozum z wysokości swej najwyższej, prawodawczej władzy moralnej bezwarunkowo potępia wojnę jako procedurę prawną, natomiast bezpośrednim obowiązkiem czyni stan pokoju, który jednak bez porozumienia między narodami nie może być ani ustanowiony, ani zabezpieczony - to musi istnieć związek szczególnego rodzaju", tj. związek pokojowy ${ }^{16}$, który zakończy stan wojny między ludźmi. Zaniechanie działań wojennych, jak wspomniano, nie jest jeszcze gwarancją stałego pokoju.

Obecnie ocena stosunku ludzi do świata i społeczeństwa wydaje się podobna do obaw, które wzbudziły rezultaty oświeceniowego rozwoju nauk, zwłaszcza wobec zburzenia wcześniejszej wizji trwałego świata, pojawienia się relatywizmu, historycyzmu, sceptycyzmu co do pewności sensu świata. Stąd logiczne wydawałoby się odpowiednie sięgnięcie do myśli zaproponowanych w kantowskim projekcie odbudowania jakiegoś porządku społecznego. Należy jednak zaznaczyć, że sytuacja do odbudowania jest inna od tej, wobec której stanął Kant. Ponowoczesność to akceptacja różnorodności, uznanie dla wolności jako ważniejszego dobra w hierarchii wartości ludzi niż bezpieczeństwo, czy odstąpienie od dalekosiężnych planów ludzkości, co może oznaczać, że chodzi o rozwiązywanie konkretnych spraw człowieka. Co szczególnie istotne, ponowoczesność wyraża brak zaufania do „wielkich wizji” celowego przebudowywania świata, do nowej wielkiej uporządkowanej przyszłości (której „chore” próby realizacji niosły europejskie izmy XX w.). Wspomniana wizja rodzi więc relatywizm. Jego źródła są jednak różne od oświeceniowych (a nawet już XVI- i XVII-wiecznych). Ówczesny relatywizm wynikał z podważenia absolutnego, niezmiennego boskiego ładu Średniowiecza.

W nawiązaniu do wizji kantowskich pojawia się projekt: pokój jako warunek społeczności ludów. Jego autor, John Rawls w latach 90. XX w. formułował myśl, że możliwa jest „rozsądnie sprawiedliwa społeczność ludów świata” wobec takich faktów, jak: „rozsądnego pluralizmu”, „demokratycznej jedności w różnorodności”, „pokoju liberalno-demokratycznego” czy „rozumu publicznego”. Te refleksje o demokratycznym społeczeństwie konstytucyjnym i pokoju nawiązywały do warunku, który umożliwi pojawienie się społeczności ludów. Wykształciły się one na granicy czasu, który obejmuje przechodzenie od tradycyjnej kultury wiejskiej do kultury urbanistycznej ${ }^{17}$. Można tu też dodać, że współczesne uzasadnienie pokoju zaczyna wyrastać z jeszcze innego - urbanistycznego uzasadnienia. Otóż wraz z przewyższeniem liczby ludności zamieszkującej miasta ponad liczbę mieszkańców wsi pojawiło się „miejskie” uzasadnienie dla pokoju. Pragmatyczna urbanistyczna wizja świata uznaje,

16 I. Kant, O porzekadle: To może być stuszne $w$ teorii, ale nic nie jest warte w praktyce. Do wiecznego pokoju. Projekt filozoficzny, tłum. M. Żelazny, Comer, Torun 1995, s. 55, 61.

17 J. Rawls, Prawo ludów, Fundacja Aletheia, Warszawa 2001, s. 180 i n. 
że warunkiem funkcjonowania rozrastających się gigantycznych miast, pozostających w globalnych związkach, jest konieczność ciągłej współpracy i współzależności ludzi. Bez tego, a więc bez pokoju miasto nie będzie żyło. Zatem coraz większy sens ma mówienie o prawie społeczności ziemskiej do pokoju w kontekście coraz większych skupisk miejskich, gdzie współzależność ludzi od siebie, od codziennej kooperacji niezmiernie wzrosła.

Można tu przypomnieć, że procesy dotyczące globalnego społeczeństwa obywatelskiego, zwłaszcza zainicjowane w 1948 r., bywają charakteryzowane jako przybierające postać przechodzenia od międzynarodowych do kosmopolitycznych norm sprawiedliwości inspirowanych wizją kantowską, tj. jego podejściem do pokoju i kosmopolitycznego prawa. O ile reguły sprawiedliwości międzynarodowej pojawiały się w rezultacie traktatów między państwami i wiązały państwa-sygnatariuszy umów, to normy kosmopolityczne odnoszą się do jednostek jako moralnych i prawnych podmiotów światowego społeczeństwa obywatelskiego. Mimo że regulacje te pochodzą z traktatów, to wiążą sygnatariuszy, nawet wbrew ich woli. Dostrzegane są tu oczywiście różne problemy, jak np. sprawa pogodzenia demokratycznej większości z kosmopolityczną sprawiedliwością czy obowiązywania regulacji zewnętrznych w warunkach istnienia woli demokratycznej legislatywy ${ }^{18}$.

Współcześnie tworzone są wizje jakiejś władzy ponadpaństwowych, globalnych korporacji czy sieci itd. Wykazuje się, że dochodzi do rozdzielania polityki, która ma charakter lokalny (państwowy), od mocy, która wychodzi poza ten obszar. Dotychczasowe instytucje utraciły bądź tracą moc, która sytuuje się w jakiejś cyberprzestrzeni czy prędkościoprzestrzeni. Ten stan globalizacji opisywany jest jako negatywny (znoszenie ograniczeń itp.). Nie towarzyszą jej adekwatne do nowego poziomu mocy instytucje „świadomego zbiorowego działania, społecznej kontroli”, tj. instytucje globalizacji pozytywnej. W każdym razie rozwój globalizacji negatywnej spowodował, że reintegracja polityki i mocy możliwa wydała się na poziomie globalnym, a nie państwa-narodu. Tę reintegrację np. Bauman umieszcza na poziomie kantowskiej propozycji allgemeine Vereinigung der Menschheit - zjednoczonej ludzkości. Jeżeli zaś chodzi o próby działań państw narodowych za pomocą mechanizmu rządowego, aby „przeciwstawić się dziurawieniu granic państwowych, otwieraniu ich dla przepływu kapitału, towarów, informacji”, to ich skutkiem ma być bieda, którą wywoła odpłynięcie kapitałów, pojawienie się bezrobocia, a także bankructwo państwa. Obecnie brakuje zarówno podmiotów panujących nad globalizacją, jak i prawa o charakterze

18 S. Banhabib, On the Philosophical Foundation of Cosmopolitan Norms, w: Law and Legal Cultures in the $21^{s t}$ Century. Diversity and Unity, Plenary Lectures, red. T. Gizbert-Studnicki, J. Stelmach, Wolters Kluwer, Warszawa 2007, s. 61. Zob. w sprawie kantowskiej koncepcji: J. Oniszczuk, Budowanie nowoczesnej polis, Oficyna Wydawnicza SGH, Warszawa 2014, s. 283 i n. 
globalnym, gdyż takiego wymiaru nie ma prawo międzynarodowe (umowy zawierane przez państwa). Wedle wspomnianej koncepcji podmiot pozytywnej globalizacji mogą utworzyć państwa-narody. Nie dostrzega się jakiejś wspólnej podstawy do ukształtowania globalnej społeczności. Jedynie w formie przypomnienia odnotowuje się wizję społeczeństwa globalnego powstającego przy zachowaniu wszelkich odrębności zwłaszcza kulturowych, religijnych, tj. habermasowską myśl o wspólnej konstytucji (idea patriotyzmu konstytucyjnego). Również integracja europejska traktowana jest jako swoiste laboratorium, a nie jako zaczątek procesów integrowania świata. Kształtowanie europejskiego podmiotu politycznego nie jest bowiem tak jakościowo złożone jak w przypadku podmiotu globalnego ${ }^{19}$.

\section{Zły i dobry pokój. Neoliberalizm jako ideologiczne źródło globalnego zła}

W powyższych uwagach pojawia się myśl o dobrym i złym pokoju. Kwestią jest, jaki ma być ten pożądany pokój, który będzie sprzyjał globalizacji. Jakim musi odpowiadać warunkom, aby służyły one wszelkiemu zdrowiu, zarówno fizycznemu, jak i psychicznemu. Zapewne można się zgodzić, że myślenie o pokoju jako warunku globalizacji i zdrowiu człowieka to ewolucyjna ścieżka, która podąża od akceptacji znośnego pokoju do dobrego pokoju. Możliwe, że o takich dobrych warunkach myślą standaryzacje praw człowieka i procedur umożliwiających wolności jednostki, zwłaszcza egzemplifikacją takiej refleksji jest ujęcie w ustawach zasad niedyskryminacji.

Na tle dotychczasowych doświadczeń naszych czasów historycznych, zainicjowanych w starożytnej Grecji przez Herodota, fundamentem wszelkiego pokoju jest sprawiedliwość i niedyskryminacja. Wytwarzanie nierówności materialnych i nierówne traktowanie ludzi wywołuje uczucia rozgoryczenia. Od niewielkiego zirytowania, przez oczekiwania naprawy niesprawiedliwości, aż po wielkie frustracje i radykalizmy, którym towarzyszy „branie” spraw we własne ręce, co oznacza czynny opór. Ten ostatni stan pojawia się zwykle w sytuacji represji w stosunku do domagających się sprawiedliwości ${ }^{20}$.

Współczesne badania naukowe i indywidualne przedstawianie doświadczeń wskazują jednak nie tyle na „poprawę” ludzkich emocji i działań, ile na zanikanie

19 Z. Bauman w: Wszystko co stałe, wyparowało, w: Idee z pierwszej ręki, antologia najważniejszych tekstów „Europy” - sobotniego dodatku do „Dziennika”, Axel Springer Polska Sp. z o.o., Warszawa 2008, s. 187-188.

20 J. Oniszczuk, Budowanie nowoczesnej polis, op.cit., s. 367-399. 
wrażliwości na sprawiedliwość. Obejmuje ona samych sprawców czynów i akceptację różnych niegodziwości przez grupy społeczne. A przecież już Homer i Hezjod ostrzegali przed niesprawiedliwością. Jeden w świecie polityki i walki, a drugi - pracy odkryli, że przekraczanie norm i niesprawiedliwość nieuchronnie prowadzą do kary, a ta obejmuje nie tylko sprawców hybris, ale też ich bliskich, a nawet całe społeczeństwo.

W każdym razie częste są oceny, że ma miejsce rozwój ogromnego, niewidzialnego zła, które wprost nie boli, ale na podobieństwo promieniowania jądrowego wywołuje totalne zniszczenia. Tym czymś ma być ideowe sprawstwo wspomnianego już neoliberalizmu, które cechuje totalitaryzm. To on ma być odpowiedzialny za złe działanie globalnych rynków, za globalny charakter niepokojów, za taki też strach. To jemu przypisuje się zglobalizowanie niewielkich zróżnicowań religijnych i kulturowych. To jego charakterowi przypisuje się spowodowanie, że wytworzył i nadal wytwarza ogromne nierównowagi i nierówności na świecie. Neoliberalizm nie sprzyja wytworzeniu globalnego zaufania i współpracy. W zubożałych społeczeństwach drobne zróżnicowania nabierają ogromnego znaczenia. W rezultacie tolerancja w świecie ludzi bez przyszłości wobec czegoś nowego czy w stosunku do innego człowieka zanika i to dotyczyć ma nawet środowisk elit umysłowych. W każdym razie można dostrzec oceny, że ideologia neoliberalna zaproponowała wartości, które z upływem czasu nie sprawdziły się, a zwłaszcza że np. możliwy jest sukces dzięki własnemu, usilnemu staraniu. Ostatecznie doszło do wytworzenia nawet w Europie wśród znacznych odłamów społecznych poczucia dezintegracji społecznej i kwestionowania ważności elit ${ }^{21}$. W zderegulowanym przez neoliberalizm świecie instytucje finansowe nie sprawdziły się jako rynkowy regulator oceny ryzyka, albowiem o ile korzyści potrafiły przejmować, to stratami obciążyły podatników w państwach. Można zauważyć, że do nierównowag i nierówności pochodzących z wcześniejszej epoki doszły nierówności i nierównowagi wygenerowane przez neokapitalizm finansowy. Zatem ma miejsce nie tylko utrzymanie szeregu „tradycyjnych” nierówności, ale doszło też do ich pogłębienia i wreszcie do wytworzenia nowych zachwiań. Nie ma większego sporu co do tego, że pewien poziom nierówności może sprzyjać postępowi, zwłaszcza gdy są stworzone realne drogi awansu, gdy każdy ma realne szanse poprawy swojej sytuacji, i to we względnej do ogarnięcia perspektywie. Jednakże w sytuacji, w której kapitalizm finansowy dokonał masowego wykluczenia i stan ten postępuje, a z nim pogłębianie dysproporcji i rozwój frustracji z różnymi przejawami degeneracji i złości ludzi, przed katastrofą pierwszym etapem może być opanowanie anarchii rynków finansowych. Towarzyszyć temu powinna zmiana neokapitalizmu

21 A. Leszczyński, Młoda Polska prawicowa, „Gazeta Wyborcza”, 14-15.11.2015, s. 17. 
finansowego na realny produkcyjno-usługowy, zmiana myślenia neoliberalnego na przebudowane myślenie liberalne.

Ten tracący na atrakcyjności świat neoliberalnej władzy nie tylko wytworzył świat złego pokoju, ale rozpoczął walkę o swoje jak najdłuższe przetrwanie za cenę dalszego pogarszania pokoju i konfliktów zbrojnych, wychodząc z założenia, że w sytuacji konfliktu ma miejsce gromadzenie wszystkich nawet niezadowolonych przy dotychczasowym mechanizmie władzy.

Świat złego pokoju miał miejsce wielokrotnie i jego przyczyny zostały opisane. Co nie znaczy, że przez ten opis owe przyczyny unieważniły się czy skonsumowały. Ważną kwestią jest zatem, co cechuje zły pokój, czy też co nie służy dobremu pokojowi. Zapewne można tu wymienić opresyjność władzy, ale też dopuszczanie przez nią do przemocy populizmu, w tym mieści się też populizm polityków lękliwie patrzących na słupki popularności i żywiących się lękami społecznymi. I dalej niejednokrotnie wymienia się pewien katalog złych cech, który obejmuje występujące w społeczeństwie przemoc, fanatyzm i przesądy, zło tendencyjności, uproszczeń, zafałszowań, niewiedzy, pustych mniemań, niechęć do mniejszości, antysemityzm, brak szacunku dla innych, nacjonalizm, nietolerancję ${ }^{22}$, narzucanie sposobu życia. Przykładem życia w warunkach złego pokoju ma być państwo, „w którym wolność słowa jest ograniczona i czasami nikt nie ma odwagi zabrać głosu. [...] Nie mamy wolności słowa, ludzie są niezadowoleni, lecz o tym nie mówią. [...] W społeczeństwie, które jest ciągle represjonowane, nigdy nie mówi się całej prawdy"23. Przeciw pokojowi ma być bierność wobec idiotyzmów i nieracjonalności, szowinizm, wprowadzanie nacjonalizmu do publicznej debaty, unikanie debaty programowej, a dalej „prymitywny nacjonalizm i religijny fanatyzm” [...], „wykorzystywanie naiwności [...] zagubionych ludzi”, niezdolność nurtów politycznych do rzeczowego dialogu. Popieranie przez nurty polityczne podziałów i „przemysłu pogardy” $i$ „cyniczne podbijanie chamskich i wulgarnych nastrojów, które owocuje falą prawicowego hejtu $\mathrm{w}$ internecie wylewającego się z forów na głównych portalach jak wybite szambo. Tak mocno, że nikt normalny nie widzi sensu włączania się w śmierdzącą fekaliami dyskusję i z tego powodu uczestnictwo w tzw. debacie obywatelskiej przypomina kąpiel w kloace"24. Niszczenie dialogu publicznego następuje też w drodze innych sposobów, jak np. dążność do „uatrakcyjnienia” debaty służącej zarabianiu pieniędzy.

22 Np. wg Bożeny Keff „Bycie Żydem w Polsce często uszkadza psychicznie, bo katolicki i nacjonalistyczny idiom polskiej kultury jest silnie antysemicki [...]. W Polsce w ogóle trudno należeć do mniejszości, obojętnie jakiej, bo naszą chorobą jest brak szacunku dla innych”. P. Pacewicz, Jak być Żydem w Polsce, „Gazeta Wyborcza", 14-15.11.2015, s. 32.

23 O. Pamuk w rozmowie: Turcy, którzy nie lubią kobiet, „Gazeta Wyborcza”, 14-15.11.2015, s. 18-19.

24 Z. Szczerek, Oskarżam, „Gazeta Wyborcza”, 31.10-1.11.2015, s. 15. 
Temu ma służyć „efekciarskie zderzanie ze sobą skrajnych tez, co zmieniło dyskusje polityczne w zapasy w kisielu - ku uciesze gawiedzi i wzroście oglądalności”25. Brak debaty politycznej widziany jest jako zagrożenie dla pokoju, gdyż sens opozycji sytuowany jest w jej sporze o jak najlepsze rozwiązanie problemu. Zwłaszcza w sytuacji ostrej walki polityczno-ideologicznej zanika współpraca sił politycznych ${ }^{26}$. Przeciw pokojowi jest uznawanie np. wolności religijnej jako żądającej od ludzi, aby „tolerowali nawet oburzające i bulwersujące praktyki religijne. Takie usytuowanie wolności sumienia i religii" interpretowane jest jako uznawanie jej pierwszeństwa w stosunku do innych wolności i prawa. Wychodzi ono ponad tradycję, że „żadne z uniwersalnych praw czy wolności nie jest $\mathrm{z}$ zasady ponad innymi”. Tylko $\mathrm{w}$ „przypadku ich kolizji w konkretnej sytuacji" ma miejsce „wyważ [anie], któremu z nich i na ile dać pierwszeństwo" 27.

Współcześnie odnotowuje się, że nawet w najbardziej rozwiniętych państwach występują kryzysy społeczno-gospodarcze, co sprawia, że nie poprawia się standard życia mieszkańców. Stąd w stosunku do imigrantów ekonomicznych przybywających do poszczególnych państw wzrastają niechęci. Podobnie nieprzyjazne nastawienie mieszkańców wielu państw ma miejsce w stosunku do uchodźców uciekających przed wojną. Zatem zwłaszcza w kryzysach gospodarczych dostrzega się źródła różnych społecznych i kulturowych podziałów oraz podważania zasad i praktyki solidarności w Europie. O etosie solidarności między różnymi narodami i kulturami wypowiadana jest ocena, że „potrzebuje obrony jak nigdy, a ludzie, którzy mogą najbardziej ucierpieć przez podziały i radykalizm, powinni wspierać się nawzajem. Nie ma wolności bez solidarności”28.

W złym pokoju ma ujawniać się zwłaszcza kłamstwo o takiej formule, która wyraża przekonanie każdego „o własnej oryginalności”. W poszukiwaniach René Girarda pojawiło się nawiązanie do człowieka Arystotelesa, którego cechą jest naśladowanie. „Dobra mimesis przejawia się w wychowaniu, kultywowaniu cnót, doskonaleniu charakteru, naśladowaniu świętych i bohaterów kultury. Ale jest też mimesis zła, ożywiana zazdrością i rywalizacją o przedmiot pragnienia, którym podzielić się nie można”. A przedmiot, którego nie da się podzielić, „wiąże się z dominacją: tu zwycięzca może być jeden. W liczbie pojedynczej występują odkrywca, król, przywódca, zawodnik". "Girard zauważył, że rywalizacja mimetyczna - «przemożna skłonność człowieka do konfrontacji z bliskimi, bliźnimi, z sąsiadami» - staje się niekiedy tak absorbująca, że pogrążeni w niej zapominamy o upragnionym przedmiocie. Stopniowo wyjaławiają

25 Ibidem, s. 14.

26 M. Król, Tylko bez negacji prosze, „Gazeta Wyborcza”, 31.10-1.11.2015, s. 17.

27 Ewa Łętowska w rozmowie: No i mamy pasztet!, „Gazeta Wyborcza”, 31.10-1.11.2015, s. 16.

28 G. Rae, Obrona solidarności, „Dziennik Gazeta Prawna”, 24-26.07.2015, s. A 23. 
życie społeczne, zmieniając je w hobbesowską «walkę wszystkich ze wszystkimi». Wszyscy pragną tego, co ma sąsiad, a jeszcze bardziej pragną upokorzyć sąsiada. Ale bywa, że nawoływanie do jedności i równości też służy wzajemnej subordynacji. «Gruntowne zniszczenie instytucji zaciera albo całkowicie niweluje zróżnicowanie hierarchii i funkcji, nadając wszystkiemu wyraz równie monstrualny, jak monotonny». Gdy znikają symboliczne rangi, które pozwalały bezkolizyjnie funkcjonować, władza zrównuje się z przemocą, a wiedza i doświadczenie tracą na znaczeniu. Wzajemność, charakteryzująca funkcjonowanie grupy, zmienia się nagle w «obopólność zniewag, ciosów i aktów zemsty oraz symptomów neurotycznych». Wyparowuje wzajemny szacunek i poszanowanie granic. Wraz z nimi nikną pozory demokracji: egalitaryzm zmienia się w urawniłowkę, równość wobec prawa - w zglajszachtowanie. Gdy wszyscy są winni, nikt nie jest za nic odpowiedzialny. Gdy każdy ma własną prawdę, społeczeństwo nie może się na niej oprzeć”. Wyjściem z tego stanu „odróżnorodnienia" ma być znalezienie ofiary dla zbiorowej przemocy. Podatne na taką selekcję ofiarniczą mają być takie grupy, jak Żydzi, mniejszości np. seksualne, osoby kalekie, obcokrajowcy, emigranci, ludzie cechujący się jakąś skrajnością, wyjątkowością, np. bogactwem, urodą, bezradnością, niezwykłą sprawnością, np. intelektualną. Wobec powyższego należy „odrzucić mimetyzm odwzajemniania, odwetu” [Girard] i „rozpoznać własny mimetyzm i skłonność do bycia prześladowcą. Tylko dzięki podobnemu rozpoznaniu i samoograniczeniu w stosunkach między ludźmi pojawia się porządek wyłączony spod prawa przemocy"29.

Złe skutki dla pokoju na świecie ma pogoń poszczególnych społeczeństw za szczęściem, kosztem innych ludzi. Terzani dostrzega, że Amerykanie mają misję ludzi na Ziemi, a jest nią „pogoń za szczęściem”. I aprobuje ten sens, ale też dodaje, że „może najpierw przestańmy ją traktować wyłącznie w aspekcie materialnym i uznajmy, że my, ludzie Zachodu nie możemy gonić za naszym szczęściem kosztem szczęścia innych i że, podobnie jak wolność, szczęście także jest niepodzielne”. Po 11 września i po najeździe na Afganistan pisarz pytał: „Czy naprawdę po to, aby ocalić nasz styl życia, miliony ludzi muszą zostać uchodźcami, muszą umierać kobiety i dzieci?”. W jego opinii nie została wstrząśnięta amerykańska ani europejska opinia publiczna, ani ofiarami, ani ograniczaniem podstawowych praw, ani głęboką niesprawiedliwością wojny. Co do wspomnianej obojętności odnośnie do losu Afgańczyków, pisarz dowodził, że ma ona podstawy w latach „niepohamowanego materializmu”, które „zmarginalizowały rolę moralności w życiu, czyniąc z takich wartości, jak pieniądze, sukces i korzyść osobista, wyłączne kryteria oceny. Nie mając czasu na zatrzymanie się i refleksję, coraz bardziej zagubiony w trybach życia, w którym rywalizacja

29 J. Tokarska-Bakir, Chciał oduczyć nas przemocy, „Gazeta Wyborcza”, 14-15.11.2015, s. 34. 
pozostawia coraz mniej miejsca na prywatność, człowiek dobrobytu i konsumeryzmu jakby zatracił umiejętność współczucia i oburzenia się. Jest skoncentrowany na sobie, nie ma oczu ani serca dla tego, co się dzieje wokół niego". W stosunku do tego rodzaju człowieka Zachodu, który jest cyniczny i niewrażliwy, egoistyczny oraz politycznie poprawny, bez względu na treść polityki, a który to człowiek jest wytworem „naszego społeczeństwa rozwoju i bogactwa”, pisarz powiedział, że przeraża go „tak samo jak człowiek z kałasznikowem wyglądający jak złoczyńca [...]. Ci dwaj się równoważą, są przykładami tego samego fenomenu: człowieka, który zapomina, że ma sumienie, który nie widzi jasno swojej roli we wszechświecie i staje się najbardziej niszczycielskim z żywych stworzeń, to zanieczyszczając wody na Ziemi, to ścinając jej lasy, to zabijając jej zwierzęta i używając coraz bardziej wyrafinowanych form przemocy wobec sobie podobnych. W Afganistanie zobaczyłem to wszystko jasno. Boli mnie to i przepełnia złością"30.

I wówczas Terzani przedstawia jeszcze inny aspekt, kolejne uzasadnienie zagrożenia dla pokoju. Otóż z rozmów przeprowadzanych z muzułmanami pisarz wywiódł „niezmienną konstatację o pozostawaniu ofiarą jakiegoś rodzaju przemocy”. Jeżeli chodzi o powód tego odczucia muzułmanów, to ma pochodzić z konfrontacji z Zachodem i jego wizją globalizacji. Pomijając moment słuszności, pisarz twierdzi, że wielu muzułmanów widzi w globalizacji instrument zachodniej „«ateistycznej i materialistycznej cywilizacji», która przez ekspansję rynku staje się coraz bogatsza i silniejsza kosztem [...] świata". W tej sytuacji religia pojawiła się jako ideologiczna broń „przeciwko nowoczesności, odbieranej jako narzucanie zachodniej kultury”. W ocenie pisarza Amerykanie poszukujący wroga znaleźli go w islamie, zaś masakra z 11 września sprawiła, że „ten wróg stał się bardzo wiarygodny” i możliwe stało się „ogłoszenie polityki, która w innych okolicznościach byłaby niedopuszczalna. Wróg został zidentyfikowany jako «terroryści» i rozpoczął się proces demonizacji tych, których Waszyngton za takich uważa”. Terzani nie dostrzegł, aby problem terroryzmu udało się rozwiązać militarnie czy przez obalanie „niewłaściwych” rządów, bowiem, jak dowodzi, „może nam się to wydawać dziwne, ale dziś na świecie jest coraz więcej ludzi, którzy nie dążą do bycia takimi jak my, którzy nie podzielają naszych marzeń"31.

Powyżej zasygnalizowano częściowo problem zakresu podmiotowego terroryzmu. Jego zachodnia jednoznaczność nie pokrywa się z innymi próbami charakterystyki. W każdym razie zapewne wspólną cechą różnych terrorystów jest sprowadzanie na ludzi zagrożeń. Otóż to założenie sprawia, że do terrorystów bywają zaliczane różne grupy przemysłowców i finansistów. Ale też dostrzega się, że akurat grupy

30 T. Terzani, op.cit., s. 30, 69, 112-113.

31 Ibidem, s. 84, 85, 91 . 
terrorystów gospodarczych są objęte ochroną i przywilejami. Zaznacza się przy tym, że nie pojawiają się przed sądami prezesi korporacji, które wywołały różne nieszczęścia na świecie, które pochłonęły niewyobrażalnie wielkie liczby ofiar. Do tych, którzy nie przestrzegali przepisów bezpieczeństwa i higieny na świecie, zaliczani bywają ci, którzy wywołali różne kryzysy społeczne, aż do wielkich kryzysów finansowo-gospodarczych o następstwach nie do oszacowania. W opinii Terzaniego „Musimy przyjąć do wiadomości, że dla innych terrorystą może być biznesmen przyjeżdżający do kraju Trzeciego Świata z torbą wypełnioną nie bombami, ale planami budowy zakładu chemicznego, który ze względu na ryzyko wybuchu i zanieczyszczenia środowiska nigdy nie mógłby powstać w bogatym kraju Pierwszego Świata". O tym swoim stwierdzeniu pisarz powiedział, że nie oznacza relatywizmu, ale jest wyrazem stanowiska, iż „terroryzm, jako sposób używania przemocy, może objawiać się w różnych postaciach, także tych ekonomicznych, i że trudno będzie dojść wspólnej definicji wroga" ${ }^{32}$.

W dotychczasowych uwagach zaznaczono, że zły pokój nie jest problematyką wewnątrzpaństwową. W planetarnym ujęciu mają miejsce konflikty zbrojne w różnych państwach, co oznacza możliwość złego globalnego pokoju. I kwestią jest poziom oraz zakres tego złego globalnego pokoju. Ale też kwestią jest wówczas jakość pokoju wewnątrz państw, które prowadzą wojnę na innych terytoriach, czy też wspierają „,interweniujące” mocarstwa. I przy tej okazji o jakości pokoju można powiedzieć w kontekście suwerenności państw. Międzynarodowo-prawne rozważania na temat równości i suwerenności państw dosyć brutalnie traktuje taki oto fakt, że wielkie państwa uznają suwerenność i niezależność tylko wielkich państw. Słabo podejmują problem suwerenności niewielkich państw. Myślą o nich w kategoriach swojej strategii. We współczesnym świecie geostrategii o mocarstwach mówi się, że nie tyle dążą do zdobycia nowych terytoriów, ile o podporządkowanie ich interesów własnym. W tej sytuacji prawo do samostanowienia postrzegane jest jako mit. Gdy coś uderza w interesy mocarstw, np. Rosji czy USA, to pojawia się interwencja, która dokonuje się pod hasłem np. „przywracania demokracji”33.

32 Ibidem, s. 50.

33 Andrej Krickovic w rozmowie, Niedźwiedziowi wolno więcej, „Gazeta Wyborcza”, 18-19.07.2015, s. 16. 


\section{Warunki dobrego pokoju. Waga etyki i nauki dla pokoju. Konieczność etycznego dialogu}

Uwagi dotyczące warunków sprzyjających złemu pokojowi umożliwiają ograniczenie zakresu wypowiedzi na rzecz warunków dobrego pokoju, które są wartościowe dla globalizacji i zdrowia człowieka. Dlatego też w istocie dla zaakcentowania można odnotować ważność takich czynników dobrego pokoju, jak: dialog, brak dyskryminacji i niesprawiedliwych nierówności, niski poziom frustracji społecznych, brak opresyjności władzy i populizmu, niewystępowanie „języka” przemocy i nienawiści, upokarzania słabszych przez instytucje i organizacje niepaństwowe, a wreszcie tolerancyjność, aby pozostać tylko przy tym wyliczeniu. I w nawiązaniu chociażby do tej ostatniej cechy pojawia się wątpienie Terzaniego, aby ludzie wychowani na nietolerancyjnym upraszczaniu byli jutro lepsi. Ale też pisarz przypomniał wypowiedź Arnolda Toynbeego: „Dzieła artystów i pisarzy żyją dłużej niż czyny żołnierzy, polityków czy kupców. Poeci i filozofowie są ważniejsi od historyków. A święci i prorocy są warci o wiele więcej niż wszyscy inni razem wzięci. Gdzie są dzisiaj święci i prorocy? Naprawdę, przydałby się chociaż jeden! Potrzebujemy nowego świętego Franciszka" ${ }^{34}$.

Szczególnie znaczące dla dobrego pokoju konieczne jest zatem zdecydowane przeciwstawianie się człowiekowi nieetycznemu, którego opisuje za Barbarą Skargą Jan Hartman, a mianowicie, że jest „zawistny, złośliwy, okrutny, jeden drugiemu nieustająco robi świństwa, okłamuje, oszukuje, zdradza. A nierzadko bije, dręczy i zabija. Z namiętności jest gotów na wszystko. Strach i głód pozbawiają go wszelkich hamulców. Na co dzień cieszy się z cudzych nieszczęść, a udaje współczucie. Chce jak najwięcej dla siebie, niewiele sobie robiąc z potrzeb innych ludzi. Wszędzie szuka zysku i korzyści. Okłamuje świat, nieustannie starając się pokazać w oczach innych ludzi jako lepszy, niż jest w istocie. Szuka współczucia i zrozumienia, samemu skąpo obdarzając nimi bliźnich. Nieraz chętnie pomaga i czyni dobro, lecz zaraz się rozgląda za kimś, kto by to zauważył i pochwalił. Będąc próżnym, wciąż poszukuje akceptacji i poważania u innych. Będąc tchórzliwym i leniwym, udaje, że nie widzi zła wokół siebie. Czeka tylko, aż inni za niego usuną niebezpieczeństwa i rozwiążą problemy tego świata. Owszem, ktoś to robi, lecz najczęściej za pieniądze. Bo interesowność łączy nas wszystkich pewnie i powszechnie, jak dwunożność i śmiertelność" 35 . Zatem to usuwanie zła w powyższym zakresie ma być warunkiem dobrego pokoju.

34 T. Terzani, op.cit., s. 46.

35 J. Hartman, Albo etyka, albo ruina, „Gazeta Wyborcza”, 3-4.10.2015, s. 38. 
Przedstawione uwagi co do możliwości dobrego pokoju, jako warunku globalizacji i dobrego pokoju, zmierzają ku ocenie, że ów pokój zwłaszcza zależy od tego najsłabszego moralnego ogniwa czy ogniw. W każdym razie jest jakiś minimalny poziom pokoju, który jest ważny dla niniejszych uwag. Możliwe, że ten kontekst wyraża syntetycznie wypowiedź, iż „Dopóki większość z nas starać się będzie oszczędzać bliźnim cierpień, dopóki trzymać się będziemy minimum uczciwości i obliczalności w stosunkach z innymi ludźmi, życie będzie trwać"36. Odpowiadając, można przypuścić jakąś trafność tej myśli, ale kwestią jest, czy pozostawanie na tym minimalnym poziomie umożliwi dobrą globalizację i zdrowie człowieka.

W każdym razie znaczące dla utrzymywania wspomnianego minimum i przeciw zakłamaniu ludzi i ich bezradności wobec zła stawiane jest remedium w postaci mechanizmu etyki ${ }^{37}$, która ma wyrastać $\mathrm{z}$ ducha poszukiwania kompromisu pomiędzy apodyktycznymi przekonaniami moralnymi. Taka etyka ma być „w sporze z niektórymi aspektami moralności publicznej oraz z etyczną bezmyślnością, polegającą na niezaprzątaniu sobie głowy jakąkolwiek refleksją moralną i na poczuciu, że jest czymś oczywistym, co jest dobre, a co złe i jak postępować należy, a jak nie należy. Arogancji i pysze moralnego dogmatyzmu etyka przeciwstawia krytyczną analizę i krytyczny - także wobec samej siebie - osąd zagadnień moralnych i utartych sądów"38.

$\mathrm{Z}$ refleksji tych wyłania się myśl o wielkiej potrzebie uczenia, kształcenia dla pokoju, albowiem w sprawach pokoju mamy globalny analfabetyzm. Kwestią jest mobilizacja do globalnej edukacji, do pokojowej alfabetyzacji. Program kształcenia zawarty był niejako w diagnozie wojny, którą pisarz podawał, tj. uważał, że „Przyczyny wojen tkwią częściej wewnątrz nas niż gdzieś na zewnątrz. Kryją się w takich uczuciach, jak pożądanie, strach, niepewność, chciwość, duma, próżność. Powoli musimy się spod nich wyzwolić. Musimy zmienić nasze podejście. Zacznijmy podejmować decyzje, które dotyczą nas i innych, kierując się bardziej moralnością, mniej zaś własnym interesem. Częściej róbmy to, co jest właściwe, zamiast tego, co jest dla nas wygodne. Uczmy dzieci uczciwości, nie sprytu" ${ }^{\prime 39}$.

Dla pokoju potrzebne jest coś więcej niż tylko zainteresowanie etyką i odpowiednim nauczaniem. Zwłaszcza gdy mają miejsce realne zagrożenia dla pokoju, gdy wybuchają wielkie kryzysy, np. gospodarcze czy polityczne. Wreszcie gdy dochodzi do naruszeń pokoju przez działania terrorystyczne. I to w takim kontekście formułowane jest pytanie przez Terzaniego: „Dlaczego nie spróbujemy poszukiwać w naszych umysłach czegoś innego niż brutalne i banalne rozwiązania - kolejne

36 Ibidem.

37 M. Szyszkowska, Etyka, op.cit., s. 140-141.

38 J. Hartman, op.cit., s. 39.

39 T. Terzani, op.cit., s. 172. 
bomby i kolejne ofiary? Mamy rozległą wiedzę, ale nie znamy naszych umysłów, a tym bardziej naszych sumień". Pisarz zastanawia się nad problemem odpowiedzi za pomocą przemocy także gdy zwraca się do Fallaci: „A ty, Oriano, naprawdę sądzisz, że stając na samym czele krucjaty przeciwko wszystkim tym, którzy nie są tacy jak Ty albo wzbudzają Twoją niechęć, przynosisz nam zbawienie [...]. Czy na pewno myślisz, że przemoc jest najlepszym sposobem pokonania przemocy?". I niezwłocznie pisarz daje wyjaśnienie, mówiąc, że „jak świat światem, nie było jeszcze takiej wojny, która położyłaby kres wszystkim wojnom". I o wojnie afgańskiej stwierdził, że także ona nie zakończy wojen. Wobec tego mówi on: „wyobraźmy sobie przyszłość odmienną od tej, jaką łudziliśmy się przed 11 września, a przede wszystkim nie poddawajmy się nieuchronności czegokolwiek, zwłaszcza wojny, czy to jako instrumentu sprawiedliwości, czy tylko zemsty". Co więcej, o wojnie z terroryzmem stwierdził, że wykorzystywana jest do militaryzacji społeczeństwa, a także „produkcji nowych rodzajów broni, wydawania większych sum na obronę”. Dlatego pisarz nalega na to, aby ludzie mówili to, co uważają za prawdę, i przedstawia przy tej okazji własną myśl o zabijaniu, tzn. że ,jest w każdym przypadku morderstwem”. Pisarz zachęca do mówienia o pokoju i wprowadzania kultury pokoju do wykształcenia młodzieży oraz w tym kontekście stawia pytanie: „Czy historia musi być nauczana jedynie jako nieskończone następstwo wojen i rzezi?"40.

A wspomniany obraz historii ma miejsce, gdy na przemoc odpowiada przemoc, zwykle bardziej okrutna itd. Wobec tego w kontekście terroryzmu i wojen pisarz stawia kwestię dla Zachodu, dlaczego nie podejmuje działań, które przerwą łańcuch przemocy. Zatem wyrażając pogląd, że „przemoc rodzi przemoc”, pisarz uważa, że „Jedynie przerywając ten cykl, można mieć nadzieję na jakieś rozwiązanie, ale nikt nie jest gotowy na zrobienie pierwszego kroku". Pisarz próbował opisać stan ludzi zachodniej cywilizacji, mówiąc: „Straciliśmy poczucie miary tego, kim jesteśmy, tego, jak delikatny i połączony jest świat, w którym żyjemy, więc nie łudźmy się, że możemy użyć «inteligentnej» dozy przemocy, aby skończyć z przerażającą przemocą innych". W tej sytuacji pojawia się sprawa zmiany dotychczasowych podejść, kwestia odpowiedniej polityki państw. W stosunku do niej Terzani za Ekkehartem Krippendorffem wyraża pogląd, że „w swej najszlachetniejszej postaci bierze się z bycia ponad zemstą i że najgłębsze korzenie kultury europejskiej można odnaleźć w niektórych mitach o Kainie czy o eryniach - mitach, które miały przypominać ludziom o konieczności przerywania zaklętego kręgu zemsty, aby cywilizacja mogła się rozwijać. Kain zabija brata, ale Bóg zakazuje ludziom mszczenia się za Abla i po naznaczeniu Kaina - znak jest też ochroną - skazuje go na wygnanie,

40 Ibidem, s. 37, 70, 171. 
gdzie założy on pierwsze miasto. Zemsta nie jest ludzką sprawą, należy do Boga”. Pisarz odnotował, że w 2002 r. „amerykański interes państwowy stoi ponad jakimikolwiek innymi zasadami”, ale też wyraził przekonanie, że „pewnego dnia polityka będzie musiała na nowo połączyć się z etyką, jeżeli chcemy żyć w lepszym świecie: lepszym w Azji i w Afryce, w Timbuktu i we Florencji”"

Krytykując amerykański typ kultury, pisarz oczekuje innego podejścia od Europy, o której mówi, że „nie może bezmyślnie podążać za Stanami tą drogą. Europa musi się odnieść do własnej historii, własnego doświadczenia wielokulturowości, żeby znaleźć siłę do dialogu, a nie do zderzenia kultur”. Dostrzegając wielkość cywilizacji m.in. w „ich przenikalności”, dodał, że staje się też ona „dużo silniejsza raczej dzięki swojej postawie moralnej niż nowej broni”. W powyższej myśli jest pragnienie opuszczenia świata arogancji zwłaszcza przez mocarstwa oraz pełne namiętności masy ich obywateli. Podawany jest sens zmiany najogólniejszej postawy mocarstwowej, gdy pisarz mówi, że „Nasza przyszłość zależy od tego, co zrobimy, jak zareagujemy na tę przerażającą prowokację, w jaki sposób będziemy od teraz postrzegać naszą prawdę w perspektywie historii ludzkości. Jak długo będziemy sądzić, że mamy monopol na «dobro» i mówić o sobie jako o «świecie cywilizowanym», ignorując resztę, tak długo nie będziemy na właściwej drodze”. I w tym kontekście mieści się nawiązująca do historii uwaga pisarza, że „Dwa i pół tysiąca lat temu pewien Hindus, zwany później oświeconym, wytłumaczył nam coś oczywistego, że «nienawiść rodzi nienawiść» i że «nienawiść można zwalczyć jedynie miłością». Niewielu go posłuchało. Może najwyższy czas to zrobić". U podstaw tego oczekiwania pisarz sytuuje historię jako umożliwiającą zrozumienie tego, że „historia się powtarza i że za każdym razem płacimy coraz wyższą cenę”. Danie pierwszeństwa rozumowi oznaczałoby „ujarzmienie namiętności”, które nadal jest „trudniejsze niż ujarzmienie świata za pomocą broni”. Jednak sięgając do przykładu postawy Gandhiego, pisarz uznaje możliwość zapanowania nad namiętnościami. I przywołuje tu myśl Gandhiego z 1925 r., że „Dopóki człowiek z własnej woli nie postawi się na ostatnim miejscu spośród innych stworzeń na Ziemi, nie będzie dla niego ratunku”42.

Kwestią są warunki umożliwiające propokojowe sprawstwo postawy moralnej. Inaczej mówiąc, chodzi o sposób likwidowania sporów dla dobrego pokoju. Na tle doświadczeń wojennych Terzani nie dostrzega konkurencji dla mechanizmu dialogu, o którym mówi, że ogromnie pomaga w rozwiązaniu konfliktów ${ }^{43}$. Na jego ważność

41 Ibidem, s. 38, 51, 106.

42 Ibidem, s. 29, 31, 37, 71, 91, 172.

43 Ibidem, s. 170. 
wskazuje się często, co wydaje się wynikać z przekonania, że kantowski stan wojny można kończyć tylko drogą rozmowy.

Ważną kwestią jest podstawowe kryterium moralne nadające sens dialogowi służącemu osiągnięciu celu w postaci dobrego pokoju i skłaniające do osiągnięcia dobrego rezultatu. Otóż trudno zakwestionować wspomnianą już wartość stałego namysłu nad ochroną człowieczeństwa w każdym, z którym kryterium związana jest zasada pomocy bliźniemu. To kryterium bliźniego umożliwia zdystansowanie w stosunku do tzw. rzeczywistości politycznej, społecznej, cechującej się wielkim słowotokiem na temat wartości, które należy w społeczeństwie chronić. Strony różnych wartości, zwłaszcza dominujący niejednokrotnie korzystają z tzw. języka nienawiści, która to dążność poczytywana jest za „poczucie utraty kontroli, stąd te desperackie próby przywrócenia dawno przez cywilizowany świat odrzuconego paradygmatu" (patriarchalnego). Przejawiają się one $\mathrm{w}$ „zmasowanym ataku na postęp i osiągnięcia umysłu ludzkiego". W późnej nowoczesności i epoce globalizmu dostrzega się sens paradygmatu „otwartości i dialogu”. W przypadku więc moralnych czy religijnych przekonań takim kryterium oceny prawdziwości tych przekonań ma być „pomoc bliźniemu”44, a nie puste manifestowanie wartości i narzucanie innym sposobu życia. Inne kryteria są bardzo wątpliwe, nie poddają się sprawdzeniu, weryfikacji co do ich słuszności.

U podstaw zmian pisarz stawia sprawę rozwiązania kwestii moralnych. Podkreślając ewolucyjność człowieka, pisarz pyta, „dlaczego nie możemy sobie wyobrazić, że ten sam człowiek, dzięki kolejnej mutacji mógłby się stać istotą bardziej duchową, mniej przywiązaną do świata materialnego, bardziej zaangażowaną w związek ze swoim bliźnim i mniej chciwym wobec reszty wszechświata. Dalej: ponieważ ta ewolucja jest zależna od sumienia, dlaczego nie spróbujemy zrobić teraz pierwszego kroku w tym kierunku". W jego mniemaniu za ogromnym postępem materialnym ludzkości nie podążył postęp duchowy, a nawet, że duchowość pogorszyła się. Stąd zaproponował, żeby ludzkość świadomie odwróciła tę dążność i odzyskała kontrolę nad umysłem traktowanym jako wyjątkowe narzędzie służące zasadniczo do „poznania i opanowania świata zewnętrznego, jakby był on jedynym źródłem naszego ulotnego szczęścia”. Zadaniem umysłu powinien powinno być też zwrócenie uwagi na świat wewnętrznym ${ }^{45}$.

44 Stanisław Obirek w rozmowie: Nie jest przesada mówienie o iranizacji Polski, „Gazeta Wyborcza”, 18-19.07.2015, s. 31.

45 T. Terzani, op.cit., s. 165-166. 


\section{Zakończenie}

Trudno nie zauważyć, że różne koncepcje uzasadniające sens pokoju i krytykujące wojny nie robią wrażenia na tych, którzy robią interesy na produkcji broni i konfliktach. Chciwość jako źródło różnorodnego $\mathrm{zła}^{46}$ zainteresowana jest stanem, gdy różne nieprawdy cieszą się swobodą i uznaniem. W warunkach konfliktu prawo i sprawiedliwość milkną na rzecz kłamstw. Nietrudno sobie wyobrazić sukces chciwości także w zakresie zawłaszczenia pokoju; ot np. wówczas, gdy zaproponuje konkurencję w dyscyplinie: kto lepiej wyrazi i uzasadni pokój. Nagroda zaś w takim konkursie o najlepszą ideę mądrościową dla pokoju byłaby kolejnym absurdem zaproponowanym przez cywilizację neoliberalno-konsumpcyjną. Co najmniej ironicznie brzmi neoliberalna dbałość o dobry pokój dla każdego człowieka.

W każdym razie problem współczesnego zapętlenia myślenia o pokoju w dominującej na świecie demokracji amerykańskiej wyraziło wystąpienie prezydenta Baracka Obamy podczas wręczania mu w 2009 r. Pokojowej Nagrody Nobla. Otóż stwierdził, że we współczesnym świecie także państwa demokratyczne dla swojej obrony nie mogą zrezygnować z przemocy. Uznał przy tym, że użycie siły militarnej ma być usprawiedliwione, co będzie miało miejsce w przypadku koniecznej obrony i że prowadzenie konfliktu zbrojnego ma się odbywać według „cywilizowanych zasad”. Jeżeli zaś chodzi o dążenie do pokoju (uzyskanie „trwałego pokoju”), to znaczenie tu mają trzy sprawy: 1) wypracowanie przez społeczność międzynarodową skutecznych metod radzenia sobie z państwami i społecznościami, które „łamią reguły i prawa”, np. międzynarodowych sankcji; 2) określenie „,natury pokoju, do którego dążymy”, gdyż pokój nie oznacza stanu braku wyraźnych cech konfliktu; trwały pokój możliwy jest tylko wówczas, gdy u jego podstaw leży powszechne przestrzeganie godności i praw jednostki, co oznacza brak akceptacji dla oceny, że różnice kulturowe mogą dopuszczać różne pojmowanie praw człowieka w poszczególnych państwach; 3) stworzenie takich warunków, aby ludzie mieli poczucie ekonomicznego bezpieczeństwa i szansę rozwoju, gdyż „Bez nadziei społeczeństwo gnije od środka” ${ }^{47}$. Pogląd ten cechuje nieakceptowanie stanowiska czysto pacyficznego, zakładającego, że uda się uzyskać pokój drogą gestów i uprzejmości. Jednocześnie może być pretekstem do stanowiska, że konflikt zbrojny jest mechanizmem służącym doporowadzeniu do pokoju. Stanowisko prezydenta zostało też zakwalifikowane jako wpisujące się w tradycję amerykańskiej wizji, że polityka zagraniczna Stanów Zjednoczonych

46 J. Oniszczuk, Budowanie nowoczesnej polis, op.cit., s. 468 i n.

47 Za P. Gillert, Pokój według Obamy, „Rzeczpospolita” 2009, s. A10. 
uczestniczy w sporze między dobrem i złem, gdzie siła USA opowiada się po stronie dobra. W każdym razie interpretacje samego prezydenta ograniczają "mesjanizm” USA, albowiem, mimo że uważa on, iż USA są najsilniejszym państwem na świecie, zaś amerykańskie wizje wolności i demokracji są uniwersalne, to jednak państwo to nie może samo rozwiązać problemów świata, którego państwa wyrosły w różnorodnych kulturach ${ }^{48}$. Do powyższej uwagi można dopisać spostrzeżenie Sormana dokonane w przededniu wyborów amerykańskich, że rewolucja konserwatywna z lat 80. XX w. w USA jeszcze trwa. W ocenie filozofa „amerykańskie serce pozostaje nadal reaganowsko-konserwatywne. Prezydent demokrata będzie mniej konserwatywny niż republikanin, ale pozostanie jednak wewnątrz kwadratu wyrysowanego przez Ronalda Reagana w 1980 roku: ograniczona ingerencja państwa, moralność, rynek i militarny aktywizm"49.

Piszący swoje listy o sensie mądrości dla pokoju Terzani chciał, aby usłyszano inny głos w sprawie wojny, aby pojawiła się ważna dyskusja. Kilkanaście lat po ich wydaniu można dostrzegać ich uniwersalność i aktualność. I nadal kwestią jest, jak wspomniano, wywołanie mądrości i przywrócenie wagi sumienia.

\section{Bibliografia}

Banhabib S., On the Philosophical Foundation of Cosmopolitan Norms, w: Law and Legal Cultures in the $21^{\text {st }}$ Century. Diversity and Unity, Plenary Lectures, red. T. Gizbert-Studnicki, J. Stelmach, Wolters Kluwer, Warszawa 2007.

Bauman Z. w: Wszystko co stałe, wyparowało, w: Idee z pierwszej ręki, antologia najważniejszych tekstów „Europy” - sobotniego dodatku do „Dziennika”, Axel Springer Polska Sp. z o.o., Warszawa 2008.

Bosacki M., Obama mówit jak posłodzony Bush, „Gazeta Wyborcza”, 12-13.12.2009.

Gajda J., Prawo natury i umowa społeczna w filozofii przedsokratejskiej, Wydawnictwo Uniwersytetu Wrocławskiego, Wrocław 1986,

Gillert P., Pokój wedtug Obamy, „Rzeczpospolita” 2009.

Hartman J., Albo etyka, albo ruina, „Gazeta Wyborcza”, 3-4.10.2015.

Kant I., O porzekadle: To może być stuszne w teorii, ale nic nie jest warte w praktyce. Do wiecznego pokoju. Projekt filozoficzny, tłum. M. Żelazny, Comer, Toruń 1995.

Krickovic A. w rozmowie: Niedźwiedziowi wolno więcej, „Gazeta Wyborcza”, 18-19.07.2015.

48 M. Bosacki, Obama mówił jak posłodzony Bush, „Gazeta Wyborcza”, 12-13.12.2009, s. 11.

49 G. Sorman, Wybory 2008 nie zmienia Ameryki, „Europa”, dod. do „Dziennika”, 29.12.2007, s. 7. 
Król M., Tylko bez negacji proszę, „Gazeta Wyborcza”, 31.10-1.11.2015.

Kuźmicz K., Pokój z punktu widzenia filozoficznoprawnego, w: Pokój i demokracja, red. M. Szyszkowska, TCHU Dom Wydawniczy, Warszawa 2009.

Leszczyński A., Młoda Polska prawicowa, „Gazeta Wyborcza”, 14-15.11.2015.

Łętowska E. w rozmowie: No i mamy pasztet!, „Gazeta Wyborcza”, 31.10-1.11.2015.

Murray O., Narodziny Grecji, Prószyński i S-ka, Warszawa 2004.

Obirek S. w rozmowie: Nie jest przesada mówienie o iranizacji Polski, „Gazeta Wyborcza”, 18-19.07.2015.

Oniszczuk J., Budowanie nowoczesnej polis, Oficyna Wydawnicza SGH, Warszawa 2014.

Oniszczuk J., Filozofia i teoria prawa, wyd. 2, C.H. Beck, Warszawa 2012.

Pacewicz P., Jak być Żydem w Polsce, „Gazeta Wyborcza”, 14-15.11.2015.

Pamuk O. w rozmowie: Turcy, którzy nie lubią kobiet, „Gazeta Wyborcza”, 14-15.11.2015.

Rae G., Obrona solidarności, „Dziennik Gazeta Prawna”, 24-26.07.2015.

Rawls J., Prawo ludów, Fundacja Aletheia, Warszawa 2001.

Sorman G., Wybory 2008 nie zmienia Ameryki, „Europa”, dod. do „Dziennika”, 29.12.2007.

Szczerek Z., Oskarżam, „Gazeta Wyborcza”, 31.10-1.11.2015.

Szyszkowska M., Etyka, Kresowa Agencja Wydawnicza, Białystok 2010.

Szyszkowska M., Odcienie codzienności, Kresowa Agencja Wydawnicza, Białystok 2009.

Terzani T., Listy przeciwko wojnie, przeł. J. Wachowiak-Finlaison, Wydawnictwo WAB, Warszawa 2012.

Tokarska-Bakir J., Chciał oduczyć nas przemocy, „Gazeta Wyborcza”, 14-15.11.2015.

Zarzycka-Bérard E., Potel J.-Y., Maspero, przyjaciel wolności, „Gazeta Wyborcza”, 14-15.11. 2015.

\section{Some remarks on the conditions of peace. Reflections on humanity}

Although the terrorist-war experience of the years since 2001 lead to conclusions that the last years negatively affected world peace, the Paris terror attacks of 2015 transformed peace into bad peace. Global terrorism is a form of expression of some form of evil, but not its explanation. The first victim of terror, as of war, is truth. The absolute power is in the hand of all justifying lie which is also influencing the absurd "shame of condemnation" of war in itself. That lie also permits the democracies to ignore the reflections on war. What is the role of the people who try to approach the world of violence with reflection? Intellectuals 
are expected to provide answers; the main function of thinking is bringing up the stories with the aim, according to the writer Terziani, of sharing wisdom and re-establishing the conscious.

Keywords: peace, violence, terror, humanitarianism, education for peace

\section{Quelques remarques des conditions de la paix. Une pensée de l'humanité}

Les expériences du terrorisme et de la guerre, subies depuis l'an 2001 jusqu'aux événements présents favorisent l'opinion que c'était la période qu'il aurait été difficile d'appeler une bonne période pour la paix dans la perspective mondiale. Par contre, à partir du moment des attentats à Paris en 2015 on peut dire que la paix a pris une forme évidente d'une mauvaise paix. Le terrorisme mondial exprime une certaine zone du mal mais il ne l'explique pas du tout. Et malheureusement, pareillement à l'époque de la guerre, c'est la vérité qui est tuée comme la première lors de la période de la terreur. Le mensonge qui justifie tout réprend le pouvoir total. Il crée aussi un absurde à la forme de la „honte de condamner” la guerre telle quelle mais aussi il permet à la démocratie de commettre un délit consistant à éviter la réflexion sur la guerre. Dans une telle situation, il apparaît une question du rôle des gens essayant de réfléchir sur le mode de la violence. Et bien, on attend la réflexion du monde des intellectuels: l'envisagement de différentes questions c'est la fonction principale de la pensée. Selon l'écrivain Terzani il s'agît surtout d'évoquer la sagesse et de restaurer la valeur de la conscience.

Mots-clés: la paix, la violence, la guerre, le terrorisme, le principe de l'humanité, l'éducation pour la paix

\section{Несколько замечаний об условиях мира. Размышления о человечности}

Терроризм и война, испытываемые с 2001 года по сегодняшний момент, способствуют оценке этого периода как времени относительно которого очень трудно сказать, что оно было хорошим для мира, рассматриваемого на глобальном уровне. После терактов в Париже в 2015 г. можно сказать, что мир приобрел форму злого мира. Глобальный терроризм выражает определенную 
область зла, хотя его не объясняет. Во время террора, равно как и войны, правда умирает первой. Полная власть переходит к все оправдывающей лжи, которая также формирует такой абсурд как "стыд осуждения" войны как таковой и позволяет демократии на злодеяние в виде уклонения от мысли о войне. В такой ситуации возникает вопрос о роли людей, пытающихся задумываться о мире насилия. От интеллектуалов ожидается размышлений; постановка вопросов является ключевой функцией мышления. По мнению писателя Терцани в особенности это касается вызова мудрости и восстановления значения совести.

Ключевые слова: мир, насилие, война, терроризм, принцип гуманности, воспитание в духе мира 